\title{
Prospects for controlling cervical cancer at the turn of the century
}

Eduardo L Franco MPH, Dr PH, (1,2) Eliane Duarte-Franco,MD, MPH, ${ }^{(1)}$ Alex Ferenczy, MD. ${ }^{(3)}$

\author{
Franco EL, Duarte-Franco E, FerenczyA. \\ Prospects for controlling cervical cancer \\ at the turn of the century. \\ Salud Publica Mex 2003;45 suppl 3:S367-S375. \\ This paper is available too at: \\ http://www.insp.mx/salud/index.html
}

\begin{abstract}
A bstract
Cervical cancer morbidity and mortality have decreased substantially during the last 50 years mostly due to successful organized or opportunistic screening with Pap cytology in high and middle income countries. In many low income countries Pap cytology screening is yet to be effectively implemented or has failed to reduce cervical cancer rates to an appreciable extent. The fact that infection with certain human papillomavirus (HPV) types is now recognized as a necessary cause of this disease has led to new research fronts on prevention of cervical cancer.Testing for H PV DN A has shown great promise as a screening tool with better sensitivity but somewhat lower specificity than Pap cytology. In combination with the latter, HPV testing has the potential to improve the negative predictive value of cytology, thus allowing for increased testing intervals, which would lower program costs with acceptable safety. Advances in cytology processing and automation have also led to new screening approaches that are increasingly gaining acceptance in high and middle income countries. For low income countries, visual inspection with acetic acid has proven to be an effective alternative to conventional Pap cytology, especially in settings where no screening programs have been implemented. Concerning primary prevention of cervical cancer, recent research on the safety and efficacy of candidate prophylactic vaccines against HPV have shown very promising results with nearly $100 \%$ efficacy in preventing persistent infections and development of cervical cancer precursors. However, policy makers are strongly cautioned
\end{abstract}

\author{
Franco EL, Duarte-Franco E, Ferenczy A. \\ Perspectivas de control de cáncer cervical \\ en el siglo XXI. \\ Salud Publica Mex 2003;45 supl 3:S367-S375. \\ Este artículo también está disponible en: \\ http://www.insp.mx/salud/index.html
}

\section{Resumen}

La morbilidad y mortalidad de cáncer cervical ha decrecido sustancialmente durante los últimos 50 años, debido principalmente a programas organizados de detección oportuna de cáncer basados en citología, particularmente en páses con altos y medianos ingreso s. Sin embargo, en muchos países de bajos ingresos el programa de detección oportuna de cáncer basado en citología apenas está siendo implantado correctamente 0 tiene fallas, por lo que no se puede apreciar el alcance para reducir las tasas de este cáncer. El hecho es que la infección con ciertos tipos de virus de papiloma humano es ahora reconocida como una causa necesaria de la enfermedad, lo que ha conducido a nuevas investigaciones frente a la prevención del cáncer cervical. Las pruebas de ADN del virus del papiloma humano se han mostrado co mo una herramienta prometedora con gran sensibilidad, pero con especificidad más baja que la citología. En combinación con citología ginecológica, la prueba del virus del papilo ma humano tiene potencial para mejorar el valor predictivo negativo de la prueba convencional, permitiendo incrementar los inter valos de periodicidad de la misma y poder disminuir los costos del programa con seguridad aceptable. Los avances en el procesamiento de la prueba de citología y auto matización de pruebas que determinan ADN del virus, han permitido nuevas propuestas de tamizaje lo que incrementa cada vez más su aceptación en países de altos y medianos ingresos. Para países de bajos ingresos, se ha probado que la inspección visual con ácido acético es una alternativa efectiva para la citología convencional, especialmente observada en sitios en

The authors' research on the epidemiology and prevention of cervical cancer is funded by grants from the Canadian Institutes of Health Research (CIHR) and from the US N ational Institutes of Health. Eduardo Franco is recipient of a Distinguished Scientist Award from the CIHR.

(1) Department of O ncology, Mc Gill University, Montreal, C anada.

(2) D epartment of Epidemiology and Biostatistics, McG ill University, Montreal, C anada.

(3) Department of Pathology, McGill University, Montreal, Canada.

Received on: N ovember 20,2002 • Accepted on: February 17, 2003

Address reprint requests to: Division of C ancer Epidemiology, McG ill University, 546 Pine Avenue W est, Montreal, Q C, Canada H2W 156. E-mail: eduardo.franco@ mcgill.ca 
to avoid deferring decisions concerning the implementation of cervical cancer screening under the expectation that a successful vaccine could obviate the need for secondary prevention strategies. This paper is available too at: http:// www.insp.mx/salud/index.html

Key words: cervical neoplasms/prevention and control; papillomavirus, human; screening; Pap cytology; liquidbased cytology los que los programas de tamizaje no han sido organizados. Referente a la prevención primaria del cáncer cervical, investigaciones recientes sobre seguridad y eficacia de la vacuna profiláctica contra el virus del papiloma humano han mostrado resultados muy prometedores con una eficacia cercana a $100 \%$ en prevención de infecciones persistentes y desarrollo de lesiones precursoras de este cáncer. Sin embargo, las políticas generadas son fuertemente cautelosas para evitar decisiones aplazadas, concernientes a la implantación del tamizaje del cáncer cervical bajo la expectativa de que la vacuna podría obviar la necesidad de estrategias de prevención secundaria. Este artículo también está disponible en: http://www.insp.mx/salud/index.html

Palabras clave: virus de papiloma humano; prevención secundaria; detección oportuna de cáncer cer vical; citología base líquida
| t is probably fair to assume that of all malignant neoplastic diseases, cervical cancer is the one in which public health prevention initiatives have been the most successful in the western industrialized world. Widespread programmatic or opportunistic screening with the Papanicolaou cytology technique, or Pap test for short, has likely contributed to reducing about threefourths of the cervical cancer burden in high income countries during the last 50 years. Additional factors contributing to further historical declines in cervical cancer incidence are the gradual decrease in population fertility (lower parity) and improvements in the western diet (more intake of fresh vegetables and fruits). Lung cancer prevention via tobacco cessation programs is still far from its target of about $80 \%$ reduction in disease incidence and screening efforts for other male or female neoplasms have more modest goals for curbing cancer incidence.

In spite of its success, Pap cytology has important limitations. A recent meta-analysis that included only studies unaffected by verification bias indicated that the average sensitivity of Pap cytology to detect cervical intraepithelial neoplasia (CIN) or invasive cervical cancer was $51 \%$ and its average specificity was $98 \% .{ }^{1}$ The Pap test's high false negative rate is thus its most critical limitation. About one-third of false-negative diagnoses are attributable to slide interpretation errors and two-thirds to poor sample collection and slide preparation. ${ }^{2}$ False-negative diagnoses have important medical, financial, and legal implications; the latter being a particularly acute problem in North America where false-negative smears are among the most frequent reasons for medical malpractice litigation. Pap cytology is based on highly subjective interpretation of morphologic alterations and is also dependent on optimally collected samples. Also, the highly repetitive nature of the work of screening many Pap smears leads to fatigue, which invariably causes errors in interpretation.

Conversely, despite the test's relatively high specificity, false-positive results are particularly common in populations with low prevalence of CIN and cancer. False-positive cytology results lead to unnecessary and frequently invasive procedures in a fairly large number of women which in turn result in increased patient anxiety and costs. The solution to minimizing errors in cytology is to improve the quality of smear taking, slide processing, and overall diagnostic performance of cervical cytology, which incur high costs for a screening program. In many settings, especially developing countries, cytology-based programs have failed to reduce cervical cancer rates substantially. ${ }^{3,4}$ This state of affairs elicited interest from the medical technology industry in developing new morphology or molecular tests with adequate sensitivity and specificity for detecting clinically significant cancer precursors. Ongoing research on the use of such new tests has led to new approaches to preventing cervical cancer and to reducing the costs of screening programs both in developed and in developing countries.

With the relatively recent understanding of the causal connection between infection by certain types (the so-called high risk types) of human papillomavirus (HPV) and cervical neoplasia ${ }^{5}$ a new paradigm of research in the detection and prevention of CIN and cervical cancer has begun. Concerning secondary pre- 
vention (screening) initiatives, this research has led to the development of tests to detect cervical HPV infection as the necessary precursor event driving cervical carcinogenesis. Use of tests to detect HPV DNA has the potential to become a useful cervical cancer screening tool either as a standalone approach or in combination with Pap cytology to augment the latter test's efficacy. Research on HPV has also led to substantial technological knowledge that is currently being used to develop candidate vaccines to prevent HPV infection and, ultimately, cervical cancer as well. Further gains in our understanding of the natural history of these infections and of the molecular biology of cervical cancer have also led to additional promising leads in prevention based on testing for genetic alterations or markers of early disease.

This overview summarizes the epidemiologic evidence for the high public health significance of cervical cancer control followed by a description of the existing prospects in all of the above areas of prevention; both primary, via control and elimination of the causes of disease, and secondary, via screening for cancer precursors (CIN) and their immediate treatment. For historical reasons, since screening by Pap cytology has been the first secondary prevention initiative in cervical cancer we review the situation with emerging screening technologies first. This is followed by a brief overview of progress in primary prevention.

\section{Cervical cancer burden throughout the world}

Cervical cancer is one of the most common malignant diseases of women. In the US each year there are approximately 12800 new cases of invasive cervical cancer with 4600 deaths due to this disease. ${ }^{6}$ In Mexico, a country with less than half of the US population, the estimated new cervical cancer cases in 2000 was 16450 , which was accompanied in the same year by 6650 deaths. ${ }^{7}$ During the last decade, an estimated 371000 new cases of invasive cervical carcinoma were diagnosed annually worldwide, representing nearly $10 \%$ of all female cancers. Its incidence is the seventh overall among all cancer sites, regardless of gender, and is third among women, after breast and colorectal cancer. ${ }^{8}$ In developing countries, cervical cancer was the most frequent neoplastic disease of women until the early 1990 's when breast became the predominant cancer site. ${ }^{9}$ The highest risk areas for cervical cancer are in Central and South America, Southern and Eastern Africa, and The Caribbean, with average incidence rates around 40 per 100000 women per year. While risk in western Europe and North America is considered relatively low at less than 10 new cases annually per 100000 women rates are 10 times higher in some parts of Northeastern Brazil, where the cumulative lifetime risk can approach $10 \% .^{10}$

Every year, an estimated 190000 deaths from cervical cancer occur worldwide, with over three-fourths of them in developing countries, where mortality from this disease is the highest among deaths caused by neoplasms. ${ }^{11}$ In general, there is a correlation between incidence and mortality across all regions but some areas seem to have a disproportionately higher mortality, such as Africa. Cervical cancer incidence and mortality in North America are relatively low. The mortality rate for Canada is the lowest among all regions. $^{2}$

Less than $50 \%$ of women affected by cervical cancer in developing countries survive longer than five years whereas the five-year survival rate in developed countries is about $66 \% .{ }^{11}$ Moreover, cervical cancer generally affects multiparous women in the early postmenopausal years. In high-fertility developing countries these women are the primary source of moral values and education for their school-age children. The premature loss of these mothers has important social consequences for the community.

\section{Technologies for cervical cancer screening}

The available screening technologies can be classified into morphology- or molecular-based approaches to recognize cytological or tissue-level abnormalities or molecular markers consistent with CIN or cervical cancer. Further distinctions can also be made based on the use of aided or unaided microscopy or of physical and electro-optical properties. Table I provides an overview of the various technologies considered in cervical cancer screening. The most relevant or promising among the technologies are summarized below.

The paradigm: Pap cytology. The Pap test is one of the first cancer screening tests and is undoubtedly the one with the best record of accomplishments in contemporary medical practice. Pap test screening targets mainly the detection of cervix cancer precursors, thereby allowing close monitoring of equivocal or low grade abnormalities on repeat tests or immediate referral for colposcopy, biopsy, and treatment of high grade or more severe lesions. Prevention of invasive cervical cancer is thus accomplished by arresting neoplastic development within the cervical epithelium before it becomes invasive. There are two types of cervical cancer screening programs: opportunistic (or sporadic) and systematic (or organized). Opportunistic screen- 
Table I

\section{MOST RELEVANT TECHNOLOGIES FOR CERVICAL CANCER SCREENING AND THEIR CHARACTERISTICS}

Approach

Morphological, recognition of Pap test cellular level abnormalities
Technology

Features

Standard of cervical cancer screening, oldest medical test, proven effectiveness in reducing incidence of and mortality from cervical cancer. Suitable for most settings, particularly middle and high income countries

Liquid-based cytology

Cleaner, more reproducible but costlier alternative to the conventional Pap test. $\mathrm{C}$ an be automated. Concern: dependence on proprietary technology. Suitable for high and middle income countries

Automated cytology

U seful in settings with mandated quality control of conventional cytology. Concern: dependence on proprietary technology. Suitable for high income countries only

Morphological, recognition of

P16IN K 4A antigen detection

Experimental, leads to more reproducible reading of Pap smears prepared with liquid cytology. Better distinction of relevant dysplastic features

molecular staining tissue level abnormalities with cation
Morphological, recognition of or without low level magnifi-

Simple visual inspection (downstaging)

Visual inspection with acetic acid pection (DVI), aided visual inspection (AVI), VIA with low level magnification (VIAM), visual inspection with Lugol's iodine (VILI)

Cervicography

Spectroscopy and speculoscopy

Morphological, recognition of tissue level abnormalities based on physical/optical properties

Polar probe

Molecular testing HPV testing (VIA ). Synonyms: direct visual ins-

Real-time but ineffective, leads to a high rate of referrals (high false positive rate)

Real-time. Sensitivity equal or better but lower specificity than conventional Pap cytology. Suitable for low income countries. 0 ngo ing investigations to obtain proof of effectiveness in reducing cervical cancer incidence and mortality

Sensitivity lower and specificity comparable or lower (setting dependent) than conventional cytology. Still dependent on proprietary technology. Suitable for high income countries as ancillary method

Experimental, real-time. Promising technology but adequate evidence of comparative efficacy still lacking. Sensitivity and specificity seems comparable to VIA (speculoscopy)

Experimental, real-time. Promising technology but evidence of comparative efficacy still lacking
More sensitive but less specific than conventional or liquid-based cytology to detect high grade lesions. In combination with cytology may allow safely increasing screening intervals, thus lowering costs. $C$ an be automated. Concern: dependence on proprietary technology. Suitable for high and middle income countries and possibly for low income countries with no cervical cancer screening ing is carried out by suggestion from a physician or health care provider when a woman presents for consultation for other health reasons. Systematic screening occurs within a system with mechanisms to identify the target population and invite all of its members to participate. There is widespread belief that systematic screening may be superior to opportunistic screening in terms of cost-effectiveness ${ }^{12}$ but this contention has been challenged. ${ }^{13}$ A discussion of available guidelines for Pap test screening is discussed elsewhere. . $^{12,14,15}$

There have been no prospective controlled trials of Pap screening efficacy, either randomized or not. The evidence for the efficacy of Pap smear screening in cervical cancer comes from two sources: a) epidemiologic studies indicating that the risk of invasive cervical cancer is substantially greater in women who have not been screened and that risk increases with time since last normal smear or with lower frequency of screening, and b) population surveillance, which indicates that cervical cancer incidence and mortality rates have decreased following adoption of cytology screening in Scandinavian countries, in Canada, and in the USA, with reductions in incidence and mortality being proportional to the extent of population coverage. ${ }^{14}$

Thin-Layer liquid-based cytology. The ThinPrep ${ }^{\mathrm{TM}}$ system (Cytyc, Inc., Boxborough, Mass., USA) and AutoCyte Prep System" (Tripath Imaging Inc., NC, USA) are 
liquid-based alternatives for the conventional method of Pap smear preparation. The sample recovered from the cervix is suspended in a cell-preserving solution instead of being placed directly on a glass slide. Virtually all cellular material is made available to the laboratory. With the conventional Pap smear, roughly $20 \%$ of the cervical cells harvested from the cervix are placed manually on the glass slide. ${ }^{16}$ In the thin layer samples, excess blood and inflammatory cells are lysed and a random sample of approximately 50000 cells are transferred by the robotic cell processor as a thin layer onto a glass slide. The slides are stained and then read by cytotechnologists. Automated thin-layer slides can improve detection of atypical cells, precursor lesions, and cancer by producing uniformly cleaner slides free of blood, inflammatory debris, and cell clumps that interfere with microscopic reading. ${ }^{17,18}$

One attractive feature of this system is the ability to save the supernatant of remaining cells in a standardized fashion for subsequent panel testing for HPV DNA and Chlamydia trachomatis. ${ }^{14}$ Another advantage of thin smears is that they can be used in conjunction with immunocytochemical staining for specific markers of dysplastic progression. The viral oncogene E7 induces increased expression of the cyclin dependent kinase inhibitor p16(ink4a) in infected cells. ${ }^{19}$ Immunostaining for p16(ink4a) using a monoclonal antibody can identify dysplastic cells with enhanced accuracy ${ }^{20}$ (Table I).

The US Food and Drug Administration (FDA) approved the ThinPrep Pap test in 1996 and the AutoCyte Prep System in 1999, as significantly superior and equivalent to the conventional Pap smear, respectively, for the detection of CIN and cervical cancer. Since then these technologies have already gained considerable penetration in the market for opportunistic cervical cancer screening in the USA, currently approaching or exceeding $50 \%$ of all smears taken in major urban centers.

In a recent evidence-based medicine review, ${ }^{21}$ the American Cancer Society concluded that liquid-based cytology was a suitable alternative to conventional cervical smears, specifying that use of this technology allows cervical screening to be performed every two years and after age 30, women who have had three consecutive, technically satisfactory normal or negative cytology results may be screened every two to three years [unless they belong to a high risk group, e.g., history of prenatal diethyls-sestrol (DES) exposure, HIV positivity, or immunosuppressive conditions].

Cytology automation. There are several automated systems being tested and marketed, ranging from robotic devices that process the cervical cell suspensions to prepare standardized thin-layer slides to computerassisted slide scanners that map the smear to detect abnormal cells, thereby separating any slides that contain suspect images for subsequent reading by a cytotechnologist. A key advantage is the potential to alleviate shortage of qualified manpower in cytopathology. Comparative trials mostly funded by the private sector are ongoing in many laboratories in North America and in Europe to answer questions related to screening efficacy and cost effectiveness of automated devices.

At present, there is only one device approved by the FDA for quality control of cytology and for primary screening for cervix cancer and its precursors in the USA, the AutoPap Screening System (Tripath Imaging Inc., NC, USA), which scans with a high speed video camera close to 200 conventional Pap smears a day. Morphometric algorithms indicate to the cytotechnologists to manually screen slides that contain the most likely abnormal cells. Conversely, those without likely abnormalities are filed (approximately 25\% to 50\%) without the need for human review. The device outperforms human review of manually screened negative smears (for quality control) by a factor of 5 to 7 , and in screening mode of low-risk women, performs as well as humans with a sort rate (no review of smears needed) of up to $50 \%$. On the other hand, the device is cumbersome and its large throughput and high perslide cost make it cost-effective only for large-volume laboratories. ${ }^{22}$

Visual inspection with acetic acid application (VIA): Visual methods have emerged as a non-technology intensive, alternative to cytology screening in low-income countries. The visual methods of screening include unaided, non-magnified visual inspection of the cervix (the so-called 'downstaging'), visual inspection with acetic acid (VIA) (also known as direct visual inspection [DVI], cervicoscopy, or aided visual inspection), VIA with low level magnification (VIAM), visual inspection with Lugol's iodine (VILI), and cervicography.

Downstaging has been shown to be inaccurate and ineffective. ${ }^{12}$ Of all visual methods VIA has been the most extensively investigated in different countries with respect to its screening accuracy in detecting cervical neoplasia. VIA involves naked eye examination of the uterine cervix, usually by a nurse or other nonmedical health worker, after swabbing it with 3-5\% acetic acid and using artificial bright illumination. Findings of characteristic acetowhite lesions are considered positive. VIA provides results immediately (also referred to as real time screening test) which allows for 
treatment and management decisions to be taken during the same patient visit. VIA seems to be at least as sensitive as, if not more sensitive than, conventional cytology to detect high-grade CIN, but it has lower specificity than the latter test. ${ }^{12}$ As it stands, VIA is the most promising low technology alternative to cytology, which led international agencies such as WHO to study its efficacy in reducing incidence of and mortality from cervical cancer. These investigations are currently ongoing. ${ }^{23}$

HPV testing in screening. There have been several studies assessing the value of HPV testing compared to the Pap test as a cervical cancer screening tool. Most investigations have used first or second generation Hybrid Capture $^{\mathrm{TM}}$ (HC) systems (Digene, Inc., Gaithersburg, MD), the only HPV test that is currently FDA approved. A few studies have used different polymerase chain reaction (PCR) protocols to detect HPV. PCR has a lower threshold of detectability for HPV DNA than the $\mathrm{HC}$ assay but $\mathrm{HC} 2$ (the second generation assay which became available commercially in 1997) has substantially improved molecular sensitivity (as compared with its first generation counterpart, the Hybrid Capture tube assay) for detecting HPV DNA that approaches that of PCR techniques. The HC2 test is a nucleic acid hybridization assay with signal amplification using microplate chemiluminescence for the qualitative detection in cervical specimens of HPV DNA of 13 highrisk types, defined as those that are frequently associated with cervical cancer: 16, 18, 31, 33, 35, 39, 45, $51,52,56,58,59,68$. PCR protocols are based on target amplification with type-specific or consensus or general primers followed by hybridization with specific oligoprobes. No PCR technique to detect HPV is yet available commercially.

Studies using HC or PCR in cervical cancer screening for detection of high grade squamous intraepithelial lesions (HSIL) (CIN of grades 2 or 3 ) have targeted European, ${ }^{24-27}$ African, ${ }^{28-30}$ Asian, ${ }^{31}$ Latin American, ${ }^{32}$ and North American ${ }^{33,34}$ populations. As shown in Table II, HPV testing has 25\%-30\% higher sensitivity than cytology in absolute terms but somewhat lower specificity, $8 \%-10 \%$ lower for detecting high grade lesions. Screening of women ages 30 or older or 35 or older tends to improve the performance of HPV testing because viral infections in this age group are less likely to be of a transient nature than those in younger women.

An important finding of some studies was the realization that the combination of cytology and HPV testing attained very high sensitivity and negative predictive values (approaching 100\%). ${ }^{31-33} \mathrm{~A}$ testing com-

\section{Table II \\ Estimates of SCREening PERformance INDICES from StUdies COMPARING HPV Testing With PaP CYTOLOGY* IN SCREENING FOR CERVICAL CANCER AND ITS PRECURSOR LESIONS. ESTIMATES SHOWN ARE FOR HIGH GRADE CIN OR CANCERS AS DISEASE OUTCOME. UNLESS NOTED OTHERWISE RESULTS APPLY TO ALL AGE GROUPS}

\begin{tabular}{|c|c|c|c|c|c|}
\hline \multirow[b]{2}{*}{ Study } & \multicolumn{2}{|c|}{ Sensitivity } & \multicolumn{2}{|c|}{ Specificity } & \multirow{3}{*}{ Characteristics } \\
\hline & $\overline{\mathrm{HPV}}$ & Pap & HPV & Pap & \\
\hline Cuzick, 1995 & 75 & 46 & 96 & 96 & \\
\hline Clavel, 1999 & 100 & 79 & 86 & 96 & \\
\hline Cuzick, 1999 & 95 & 79 & 94 & 99 & \\
\hline Kuhn, 2000 & 88 & 78 & 82 & 97 & \\
\hline \multirow[t]{2}{*}{ Ratnam, 2000} & 68 & 27 & 91 & 96 & All ages, bias-adjusted ${ }^{\ddagger}$ \\
\hline & 82 & 40 & 94 & 97 & Age $\geq 30$, bias-adjusted ${ }^{\ddagger}$ \\
\hline Schiffman, 2000 & 88 & 78 & 89 & 94 & \\
\hline W right, 2000 & 84 & 61 & 83 & 96 & \\
\hline Schneider, 2000 & 89 & 20 & 94 & 99 & Bias-adjusted ${ }^{\ddagger}$ \\
\hline Belinson, 2001 & 95 & 87 & 85 & 94 & Liquid-based cytology \\
\hline Blumenthal, 2001 & 80 & 44 & 61 & 91 & Bias-free $\neq$ \\
\hline \multirow[t]{2}{*}{ Clavel, 2001} & 100 & 68 & 87 & 95 & All ages \\
\hline & 100 & 58 & 90 & 96 & Age $>30$ \\
\hline Kulasingam, 2002 & 63 & 36 & 83 & 96 & Age $\geq 30$, bias-adjusted \\
\hline
\end{tabular}

* LSIL threshold (majority of studies) or LSIL or persistent ASC US (Kulasingam, 2002)

₹ Verification bias either adjusted for or avoided by having colposcopies performed in all subjects

bination with such a high negative predictive value could potentially allow increasing screening intervals safely, e.g., from 1-3 years to 3-5 years, depending on the population and risk profile. The drawback of this approach is the loss in specificity with respect to either test in isolation due to the excessive number of patients who would need to be referred for colposcopy, many of which will turn out to be false positive results. Resource-rich countries can absorb the extra costs related to the secondary triage of cases that will be referred via a dual-testing screening approach because this strategy may be cost saving upon long term assessment, via the reduced patient flow for primary screening clinics. Economic models based on valid estimates of screening efficacy across different settings are urgently needed to assess the potential benefit of combined screening in relation to its costs.

One of the advantages of HPV DNA testing is that it is suitable for self-sampling. In one study of 1365 South-African women aged 35 to 65 years old the rate of detecting cervical cancer precursors was compara- 
ble between self-sampling for HPV testing (66.1\%) and conventional cytology performed by healthcare providers $(67.9 \%){ }^{29}$ Self-sampling is likely to improve compliance, which is particularly appealing in countries in which cultures have social and religious limitations on the acceptability of vaginal examinations.

A few large randomized controlled trials of HPV testing in primary cervical cancer screening are currently ongoing. Of note are the UK HPV in Addition to Routine Testing (HART) investigation, ${ }^{35}$ the UK "A Randomized Trial In Screening To Improve Cytology" (ARTISTIC) [Henry Kitchener, personal communication], and the Canadian Cervical Cancer Screening Trial (CCaST), led by the authors.

HPV testing for secondary triage of cervical abnormalities. One of the first applications of HPV DNA testing in clinical practice was for the triage of women referred for colposcopy because of an abnormal Pap smear. The adoption nearly 15 years ago of the Bethesda system for cervical cytology reports ${ }^{36}$ has dramatically increased the proportion of Pap smears with cytological abnormalities that merit clinical attention. The new terminology increased the overall proportion of low grade lesions by combining the original mild dysplasia category with cytological abnormalities consistent with koilocytotic atypias, thus creating the low grade intraepithelial lesion (LSIL) designation, and created a new category for borderline lesions, the "atypical squamous cells of undetermined significance", or ASCUS. While there is consensus that women with high grade SIL (HSIL) on cytology need immediate referral for colposcopy, uncertainty has existed about management options for ASCUS and LSIL. Such cases have been managed by immediate colposcopy, repeat Pap testing, and HPV DNA testing, the latter two tests either alone or in combination.

Preliminary evidence that HPV DNA testing has clinical value in triaging ASCUS or LSIL has been provided by several studies conducted in the early and mid90's, which indicated for the most part that HPV DNA testing could increase the sensitivity of a repeat Pap when used as an adjunct test. ${ }^{37}$ Two recent large-scale studies (the Kaiser-Permanente and the ALTS investigations) have provided more conclusive evidence of benefit for women of all ages, specifically for the triage of ASCUS smears. ${ }^{38,39}$ HPV DNA testing is significantly more sensitive (about 10\% higher in absolute terms) than repeat Pap cytology in detecting histologically confirmed HSIL among such cases, even when the latter is used at a lower threshold of positivity. These two studies have shown also that the HPV and Pap tests have comparable specificities in ASCUS triage.
While the value of HPV DNA testing in the triage of ASCUS smears is well established, it cannot be recommended as a tool to orient clinical management of women with a referral LSIL smear. A component of the aforementioned ALTS trial found that more than four-fifths of such cases are HPV positive. Given the very high rate of HPV positivity (with high risk types) among women with LSIL there would be limited or no value in using HPV DNA testing in triaging such cases for colposcopy. ${ }^{40}$ Recent analyses from the latter study using restriction on age or viral load corroborate this interpretation. ${ }^{41}$

\section{Primary prevention of cervical cancer}

Recognition that HPV infection is the central cause of cervical cancer and its precursor $\mathrm{CIN}^{42}$ has created new research fronts in primary prevention of this disease.

Primary prevention by education. Primary prevention of cervical cancer can be achieved through prevention and control of genital HPV infection. Health promotion strategies geared at a change in sexual behavior targeting all sexually-transmitted infections of public health significance can be effective in preventing genital HPV infection. ${ }^{14}$ Although there is consensus that symptomatic HPV infection (genital warts) should be managed via treatment, counseling, and partner notification, active case-finding of asymptomatic HPV infection is currently not recommended as a control measure. Further research is needed to determine the effectiveness of such a strategy.

Primary prevention by HPV vaccination. Two main types of HPV vaccines are currently being developed: prophylactic vaccines to prevent HPV infection and associated diseases, and therapeutic vaccines to induce regression of precancerous lesions or remission of advanced cervical cancer. Strictly speaking, however, the latter type cannot be considered as part of a primary prevention effort because of its curative intent.

DNA-free virus-like particles (VLP) synthesized by self-assembly of fusion proteins of the major capsid antigen L1 induce a strong humoral response with neutralizing antibodies. VLPs are thus the best candidate immunogen for HPV vaccine trials. Such vaccines are already under evaluation in efficacy and safety trials in different populations sponsored by pharmaceutical companies (e.g., Glaxo Smithkline and Merck) and by the US National Institutes of Health and can produce strong type-specific antibody responses. ${ }^{43}$ The preliminary results of one such a trial were extremely promising. ${ }^{44}$ It indicated that an HPV 16 VLP vaccine 
was 100\% effective in preventing acquisition of persistent infection with HPV 16 and 90\% effective in preventing any incident HPV 16 infection, transient or persistent. As a noteworthy secondary finding was the fact that all HPV 16 associated CIN cases occurred in the non-vaccinated group.

Immunization against HPV may have greatest value in developing countries, where $80 \%$ of the global burden of cervical cancer occurs each year and where Pap screening programs have been largely ineffective. In this regard, many issues are being considered by those involved in HPV vaccine research. Long-lasting protection against HPV 16 may translate into prevention of nearly half of all cervical cancers. Although evidence from controlled trials has been obtained mostly for monovalent or bivalent vaccines there is a general consensus that a future vaccine will have to include at least the most common high risk HPV types associated with the disease to be largely effective against cervical cancer. Other concerns include the development and standardization of surrogate assays for protective antibodies, the definition of the target population to be vaccinated, agreement on trial endpoints, e.g., early (HPV) vs. late (lesions) for prophylactic vaccines and criteria for regression of established lesions for therapeutic vaccines, the establishment of roles for the public sector and regulatory agencies; identification of funding sources for studies in which the pharmaceutical sector will not be involved, and last, but not least, coordination with secondary prevention strategies.

\section{Conclusions}

In summary, although much has been gained in the last 50 years in reducing the burden of cervical cancer by organized or opportunistic cytology screening, the benefits have been seen particularly in high and middle income countries. Cervical cancer remains an important public health problem in low income countries, especially in Africa and in Latin America. Despite its history of success when performed in well controlled conditions, the Pap test has several limitations. Efficacious alternatives are available but their cost effectiveness needs to be assessed in different settings. Some of the most promising alternatives to conventional Pap cytology, such as HPV testing or liquid-based cytology, may be effective in high and middle countries that have not yet made substantial investments in establishing Pap-based screening programs or overhauling existing ones that seem inadequate. In this regard, an important concern is the possible dependence on a proprietary method that is controlled by one or a few commercial monopolies. On the other hand, VIA seems to be a viable and cost effective option for low income countries with little infrastructure resources.

Public health authorities in middle and low income countries have monitored closely the ongoing debate on the role of new screening technologies. Between the fear of increased health care costs consequent to the adoption of a new screening test and the promising results coming from the research front on HPV vaccines it is tempting to take a wait-and-see attitude concerning cervical cancer prevention. It is not unreasonable to consider that this posture could lead to decreased funding for cervical cancer screening in the false hope that HPV vaccines will be available soon to eradicate the disease. This scenario could prove disastrous by abolishing the hard-earned gains made in the last half century in reducing cervical cancer morbidity and mortality by Pap screening.

\section{References}

1. N anda K, McC rory DC, Myers ER, Bastian LA, Hasselblad V, Hickey JD et al. Accuracy of the Papanicolaou test in screening for and follow-up of cervical cytologic abnormalities:A systematic review. Ann Intern Med 2000;132:810-819

2. Franco EL, D uarte-Franco E, Ferenczy A. Cervical cancer: Epidemiology, prevention, and role of human papillomavirus infection. C an Med Assoc J 2001;164:1017-1025.

3. Koss LG. The Papanicolaou test for cervical cancer detection.A triumph and a tragedy. JAMA 1989;261:737-743.

4. McG oogan E.Advantages and limitations of automated screening systems in developing and developed countries. In: Franco EL, Monsonego J, ed. N ew developments in cervical cancer screening and prevention. London: Blackwell, 1997:317-322.

5. IARC W orking Group. Human papillomaviruses. IARC Monographs on the evaluation of carcinogenic risks to humans. International A gency for Research on Cancer, Lyon: vol. 64, 1995;

6. Ries LAG, Eisner MP, Ko sary CL, Hankey BF, Miller BA, Clegg L et al, ed. SEER Cancer Statistics Review, 1973-1997. Bethesda (MD) N ational Cancer Institute, 2000.

7. Ferlay J, Bray F, Pisani P, Parkin D M. GLO BO CAN 2000: Cancer incidence, mortality and prevalence worldwide. Lyon: IARC Press, 2001; Version 1.0. IARC CancerBase N 0.5.

8. Parkin D M, Pisani P, Ferlay J. Estimates of the worldwide incidence of 25 major cancers in 1990. Int J Cancer 1999;80:827-841.

9. Parkin D M, Pisani P, Ferlay J. Estimates of the worldwide incidence of 18 major cancers in 1985. Int J Cancer 1993;54:594-606.

10. Muir C, W aterhouse J, Mack T, Powell J,W helan S. C ancer incidence in five continents. Lyon: International Agency for Research on $\mathrm{C}$ ancer, 1987; Vol.V. IARC Scientific Publications N 0. 88

11. Pisani P, Parkin D M, Bray F, Ferlay J. Estimates of the worldwide mortality from 25 cancers in 1990. Int J Cancer 1999;83:18-29.

12. Miller AB, N azeer S, Fonn S, Brandup-Lukanow A, Rehman R, Cronje

$H$, Sankaranarayanan $R$ et al. Report on consensus conference on cervical cancer screening and management. Int J C ancer 2000;86:440-447.

13. G ustafsson L, Sparen P, Gustafsson M, W ilander E, Bergstrom R, Adami HO . Efficiency of organised and opportunistic cytological screening for cancer in situ of the cervix. Br J Cancer 1995;72:498-505. 
14. Franco EL, Ferenczy A. Cervix. In: Franco EL, Rohan TE, ed. Cancer precursors: Epidemiology, detection, and prevention. N ew York: Springer-Verlag, 2002:249-286.

15. Franco EL, D uarte-Franco E, Rohan TE. Evidence-based policy recommendations on cancer screening and prevention. $C$ ancer Detect Prev 2002;26:350-361.

16. Ferenczy A, Franco EL. Cervical-cancer screening beyond the year 2000. Lancet 0 ncol 2001;2:27-32.

17. Ferenczy A, Robitaille J, Franco E,Arseneau J, Richart RM,W right TC Conventional cervical cytologic smears vs. thin prep smears. A paired comparison study on cervical cytology. Acta Cytol 1996;40:1136-1142. 18. Hutchinson ML, Zahniser DJ, Sherman ME, Herrero R,Alfaro M, Bratti MC et al. Utility of liquid-based cytology for cervical carcinoma screening: Results of a population-based study conducted in a region of Costa Rica with a high incidence of cervical carcinoma. C ancer 1999:87:48-55

19.Von Knebel-D oeberitz M. N ew markers for cervical dysplasia to visualise the genomic chaos created by aberrant oncogenic papillomavirus infections. Eur J C ancer 2002;38:2229-2242. 20. Bibbo M, Klump W J, D eC ecco J, Kovatich AJ. Procedure for immunocytochemical detection of P16IN K 4A antigen in thin-layer, liquid-based specimens. Acta Cytol 2002;46:25-29.

21. Saslow D, Runowicz CD, Solomon D, Moscicki AB, Smith RA, Eyre HJ et al.American Cancer Society. G uideline for the early detection of cervical neoplasia and cancer. CA Cancer J Clin 2002;52:342-362. 22.W ilbur DC, Prey MU, Miller W M, Pawlick GF, Colgan TJ.The AutoPap system for primary screening in cervical cytology. Comparing the results of a prospective, intended-use study with routine manual practice. Acta Cytol 1998; 42: 214-220.

23. Sankaranar ayanan R, Budukh AM, Rajkumar R. Effective screening programmes for cervical cancer in low- and middle-income developing countries. Bull W orld Health O rgan. 2001;79:954-962.

24. C uzick J, Szarewski A, Terry G, Ho L, Hanby A, Maddox PM et al. Human papillomavirus testing in primary cervical screening. Lancet 1995;345:1533-1536.

25. C uzick J, Beverley E, Ho L,Terry G, Sapper H, Mielzynska I et al. $\mathrm{HPV}$ testing in primary screening of older women. $\mathrm{Br} J \mathrm{C}$ ancer 1999;81:554-558.

26. Schneider A, Hoyer H, Lotz B, Leistritza S, Kuhne-H eid R, N indl I et al. Screening for high-grade cervical intra-epithelial neoplasia and cancer by testing for high-risk HPV, routine cytology or colposcopy. Int J Cancer 2000;9:29-34.

27. Clavel C, Masure M, Bory JP, Putaud I, Mangeonjean C, Lorenzato M et al P. Human papillomavirus testing in primary screening for the detection of high-grade cervical lesions:A study of 7932 women. $\mathrm{Br}$ J Cancer 2001; 84:1616-1623.

28. Kuhn L, D enny L, Pollack A, Lörincz A, Richart RM, W right TC. Human papillomavirus DNA testing for cervical cancer screening in low-resource settings. J N atl Cancer Inst 2000;92:818-825.

29. W right TC Jr, D enny L, Kuhn L, Pollack A, Lörincz A. HPV D N A testing of self-collected vaginal samples compared with cytologic screening to detect cervical cancer. JA MA 2000;283:81-86. 30. Blumenthal PD, G affikin L, C hirenje ZM, McG rath J,W omack S, Shah $K$.Adjunctive testing for cervical cancer in low resource settings with visual inspection, H PV, and the Pap smear. Int I Gynaecol 0 bstet 2001;72:47-53.

31. Belinson J, Q iao YL, Pretorius R, Zhang W H, Elson P, Li L, Pan Q J et al. Shanxi Province cervical cancer screening study:A cross-sectional comparative trial of multiple techniques to detect cervical neoplasia. Gynecol 0 ncol 2001;83:439-444.

32. Schiffman M, Herrero R, Hildesheim A, Sherman ME, Bratti M, $W$ acholder $S$ et al. HPV DN A testing in cervical cancer screening: Results from women in a high-risk province of C osta Rica. JAMA 2000;283:87-93.

33. Ratnam S, Franco EL, Ferenczy A. Human papillomavirus testing for primary screening of cervical cancer precursors. $C$ ancer Epidemio Biomarkers Prev 2000;9:945-951.

34. Kulasingam SL, Hughes JP, Kiviat N B, Mao C, W eiss N S, Kuypers JM et al. Evaluation of human papillomavirus testing in primary screening for cervical abnormalities: Comparison of sensitivity, specificity, and frequency of referral. JAMA 2002; 288: 1749-1757.

35. Cuzick J, for the HART Study Group. Baseline results for the HART multicentre HPV screening study of older women. 19th International Papillomavirus Conference; Florianópolis, September 1-7, 2001 Brazil (abstract \# P-4).

36. Solomon D.The 1988 Bethesda system for reporting cervical/vaginal cytologic diagnoses. J Clin Cytol Cytopathol 1989;33:567-574. 37. Franco EL, Ferenczy A.Assessing gains in diagnostic utility when human papillomavirus testing is used as a Pap smear adjunct for triaging women with cervical abnormalities. Am J O bstet Gynecol 1999;181: 382-386. 38. Manos MM, Kinney W K, Hurley LB, Sherman ME, Shieh-N gai J, Kurman RJ et al. Identifying women with cervical neoplasia: U sing human papillomavirus DNA testing for equivocal Papanicolaou results. JAMA 1999; 281:1605-1610.

39. Solomon D, Schiffman M,Tarone R. Comparison of three management strategies for patients with atypical squamous cells of undetermined significance: Baseline results from a randomized trial. J $\mathrm{N}$ atl C ancer Inst 2001:93:293-299.

40. ALTS G roup. Human papillomavirus testing for triage of women with cytologic evidence of low-grade squamous intraepithelial lesions: Baseline data from a randomized trial.The atypical squamous cells of undetermined significance/low-grade squamous intraepithelial lesions triage study (ALTS) Group. J N atl C ancer Inst 2000;92:397-402. 41. Sherman ME, Schiffman M, C ox JT. Effects of age and human papilloma viral load on colposcopy triage: $D$ ata from the randomized atypical squamous cells of undetermined significance/low-grade squamous intraepithelial lesion triage study (ALTS). J N atl C ancer Inst 2002;94:102-107.

42. Bosch FX, Lörincz A, Muñoz N , Meijer CJ, Shah KV.The causal relation between human papillomavirus and cervical cancer. J C lin Pathol 2002:55: 244-265.

43. Harro CD, Pang YY, Roden RB, Hildesheim A,W ang Z, Reynolds MJ et al. Safety and immunogenicity trial in adult volunteers of a human papillomavirus $16 \mathrm{~L} 1$ virus-like particle vaccine. J $\mathrm{N}$ atl Cancer Inst 2001;93: 284-292.

44. Koutsky LA, Ault KA, W heeler CM, Brown DR, Barr E,Alvarez FB et al. A controlled trial of a human papillomavirus type 16 vaccine. $N$ Engl J Med 2002;347:1645-1651. 